\title{
SISTEM PENDETEKSIAN PENYIMPANGAN TINGKAH LAKU ANAK USIA O SAMPAI 3 TAHUN DENGAN METODE BAYESIAN
}

\author{
Diana Laily Fithri \\ Progdi Sistem Informasi Fakultas Teknik Universitas Muria Kudus \\ Gondang manis POBOX 53 Bae Kudus \\ Email : dila_fitri@yahoo.com
}

\begin{abstract}
ABSTRAK
Deteksi dini untuk penyimpangan tingkah laku pada anak usia 0 sampai 3 tahun menggunakan metode Bayesian merupakan suatu deteksi yang dapat digunakan oleh orang tua untuk menentukan jenis penyimpangan yang terjadi pada bayi. Setiap perkembangan tingkah laku pada tahap usia seorang anak pada usia 0 sampai 3 tahun mengalami tingkah laku sesuai dengan usianya. Jika tidak sesuai dengan tahapan seusianya, ada kemungkinan anak tersebut mengalami keterlambatan perkembangan. Dalam sistem ini pengguna dapat memilih tingkah laku mana saja yang sudah dapat dilakukan oleh anak tersebut, sehingga akan menghasilkan sebuah diagnosa berupa jenis-jenis keterlambatan. Metode yang digunakan dalam sistem ini adalah metode Bayesian. Variabel yang digunakan untuk deteksi dini untuk penyimpangan tingkah laku pada anak yaitu sikap duduk, tengkurap, merangkak, memindahkan barang dari tangan satu ke tangan yang lain, memegang benda kecil, bergembira dengan melempar benda, mengeluarkan kata-kata, mengenal muka anggota keluarga, berpartisipasi dalam permainan tepuk tangan dan sembunyi-sembunyian. Tingkat hasil deteksi penyimpangan tingkah laku pada anak usia 0-3 tahun dapat dilihat dengan menggunakan keterlambatan motorik kasar, keterlambatan motorik halus, keterlambatan bicara, keterlambatan sosialisasi. Semakin besar nilai keterlambatan dari variabel diatas, maka semakin besar tingkat penyimpangan tingkah laku pada anak tersebut.
\end{abstract}

Kata Kunci : Bayesian, perkembangan, anak, deteksi, tingkah laku, diagnosa

\begin{abstract}
Early detection of deviations behavior in children aged 0 to 3 years using a Bayesian method of detection that can be used by parents to determine what kind of deviation that occurs in infants. Each developmental stage behavior at the age of a child at the age of 0 to 3 years of age-appropriate behavior. If it is not in accordance with the stages of his age, the child is likely to experience developmental delays. In this system the user can choose whichever behavior can already be done by the child, so it will produce a diagnosis such as the types of delays. The method used in this system is the Bayesian method. Variables that are used for early detection of irregularities in the child 's behavior is the attitude of sitting, prone, crawl, move goods from one hand to the other hand, hold small objects, delighted with throwing objects, the words, familiar face family members, participated and applause in the game hide-and. Rate of deviation detection behavior in children aged 0-3 years can be seen using gross motor delay, fine motor delay, speech delay, delay socialization. The greater the delay value of the variables above, the greater the degree of deviation in the child's behavior.
\end{abstract}

Keywords:Bayesian, development, children, detection, behavior, diagnosis

\section{PENDAHULUAN}

Pendeteksian suatu penyakit atau penyimpangan tingkah laku banyak digunakan dalam bidang kesehatan karena pendeteksian suatu penyakit dipandang sebagai cara penyimpanan pengetahuan 
sistem pakar pada bidang tertentu dalam program komputer sehingga keputusan dapat diberikan dalam melakukan penalaran secara cerdas.

Deteksi untuk penyimpangan tingkah laku pada anak usia 0 sampai 3 tahun. mengalami tingkah laku sesuai dengan usianya. Tingkah laku tersebut termasuk sebuah patokan apakah anak tersebut mengalami perkembangan atau tidak. Dan pada usia 0 sampai 3 tahun pasti setiap ibu sangat memperhatikan perkembangan anaknya. Dan jika anak tidak bertingkah sesuai dengan usianya maka setiap ibu akan sangat khawatir. Para ibu akan sangat takut dan tidak tahu anaknya tersebut mengalami keterlambatan pertumbuhan jenis apapun.

Oleh karena itu, dengan dibuatnya sistem ini berharap supaya para ibu dapat mengetahui apakah tingkah laku anaknya termasuk dalam penyimpangan atau tidak. Selain itu para ibu juga dapat mengetahui solusi apa yang harus dilakukan jika anaknya mengalami penyimpangan tersebut. Sedangkan tujuan dibuatnya sistem ini supaya para ibu lebih perhatian terhadap anaknya yang masih berusia dini, sehingga para ibu dapat mengetahui apakah anaknya termasuk melakukan penyimpangan atau tidak. Sistem ini juga dapat membantu para ibu jika anaknya mengalami tingkah laku yang menyimpang, sehingga para ibu bisa mengatasi atau mengetahui solusi apa yang harus dilakukan terhadap anaknya.

\section{TINJAUAN PUSTAKA}

Menurut Dhani (2009) dalam skripsi yang berjudul Perancangan Sistem Pakar Untuk Diagnosa Penyakit Anak menjelaskan bahwa sistem pakar merupakan salah satu cabang keerdasan buatan yang mempelajari bagaiana "mengadopsi" cara seorang pakar berfikir dan bernalar dala enyelesaikan satu permasalahan, dan bagaimana membuat keputusan dan mengambil kesimpulan berdasarkan pengetahuan itu[2].

Menurut Destiani (2012) dalam jurnal yang berjudul Perancangan Analisa Sistem Pakar Penyakit Kulit Pada Anak menerangkan bahwa sistem pakar (epert system) adalah siste yang berusaha mengadopsi pengetahuan manusia ke komputer, agar komputer dapat menyelesaikan masalah yang seperti biasa dilakuakan oleh para ahli. Sistem pakar yang baik dirancang agar dapat menyelesaikan suatu permasalahan tertentu dengan meniru kerja dari para ahli[1].

Menurut Listiyono (2008) dalam jurnal yang berjudul "Merancang dan Membuat Sistem Pakar" menyatakan bahwa dalam bidang kedokteran teorema Bayes sudah dikenal tetapi teori ini lebih banyak diterapkan dalam logika kedokteran modern. Teorema ini lebih banyak diterapkan pada hal-hal yang berkenaan dengan diagnosa secara statistic yang berhubungan dengan probabilistik serta kemungkinan dari penyakit dan gejala-gejala yang berkaitan[6].

Menurut Vina Adriany (2011 ) dalam jurnal yang berjudul " Optimalisasi Perkemangan Anak Usia Dini Melalui Kegiatan Penyuluhan Deteksi Dini Tumbuh Kembang anak " menyatakan bahwa Perkembangan anak usia dini memegang peranan yang sangat penting dalam perkembangan seorang individu. Agar seorang anak memiliki perkembangan yang baik, maka perlu ada deteksi dini tumbuh kembang anak yang memiliki tujuan tercapainya optimalisasi perkembangan seorang anak. Sangat disayangkan masih sedikit orang tua yang $\mathrm{m}$ emiliki kesadaran untuk melakukan deteksi dini tumbuh kembang anak[7]

\section{METODOLOGI PENELITIAN}

\subsection{Metode Pengembangan Sistem}

Model ini telah diperoleh dari proses engineering lainnya. Model ini menawarkan cara pembuatan perangkat lunak secara lebih nyata[5].Langkah -langkah yang penting dalam model ini :

a. Penentuan dan analisis spesifikasi

Jasa, kendala dan tujuan dihasilkan dari konsultasi dengan pengguna sistem. Kemudian semuanya itu dibuat dalam bentuk yang dapat dimengerti oleh user dan staff pengembang. 
b. Desain sistem dan perangkat lunak

Proses desain sistem membagi kebutuhan-kebutuhan menjadi sistem perangkat lunak atau perangkat keras. Proses tersebut menghasilkan sebuah arsitektur sistem keseluruhan. Desain perangkat lunak termasuk menghasilkan fungsi sistem perangkat lunak dalam bentuk yang mungkin ditransformasi ke dalam satu atau lebih program yang dapat dijalankan.

c. Implementasi dan ujicoba unit

Selama tahap ini desain perangkat lunak disadari sebagai sebuah program lengkap atau unit program. Uji unit termasuk pengujian bahwa setiap unit sesuai spesifikasi.

d. Integrasi dan ujicoba sistem

Unit program diintegrasikan dan diuji menjadi sistem yang lengkap untuk meyakinkan bahwa persyaratan perangkat lunak telah dipenuhi. Setelah ujicoba, sistem disampaikan ke customer.

e. Operasi dan pemeliharaan

Normalnya, ini adalah phase yang terpanjang. Sistem dipasang dan digunakan. Pemeliharaan termasuk pembetulan kesalahan yang tidak ditemukan pada langkah sebelumnya. Perbaikan implementasi unit sistem dan peningkatan jasa sistem sebagai kebutuhan baru ditemukan.

\subsection{Probabilitas Bayesian}

Menurut Arhami (2005) Probabilitas Bayesian adalah salah satu cara untuk mengatasi ketidakpastian dengan menggunakan Formula Bayes yang dinyatakan sebagai berikut:

$$
P(H \mid E)=\frac{P(E \mid H) P(H)}{P(E)}
$$

Dimana :

$P(H \mid E)$ : Probabilitas hipotesa $\mathrm{H}$ jika terdapat evidence $\mathrm{E}$

$P(E \mid H)$ : Probabilitas munculnya evidence $\mathrm{E}$ jika diketahui hipotesa $\mathrm{H}$

$P(H) \quad$ : Probabilitas hipotesa $\mathrm{H}$ tanpa memandang evidence apapun.

$P(E) \quad$ : Probabilitas evidence $\mathrm{E}$

Penerapan teorema Bayes untuk mengatasi ketidakpastian, jika muncul lebih dari satu evidence dituliskan sebagai berikut :

Dimana :

$$
P(H \mid E, e)=P(H \mid E) \frac{P\left(e \mid E_{u} H\right)}{P(e \mid E)}
$$

$$
\begin{array}{ll}
\mathrm{e} & \text { : evidence lama } \\
\mathrm{E} & \text { : evidence baru } \\
P\left(H \mid E_{y} e\right) & \text { : probabilitas adanya hipotesa } \mathrm{H}, \text { jika muncul evidence } \mathrm{E} \text { dari evidence lama } \\
& \quad \mathrm{e} \\
P\left(e \mid E_{s} H\right) & \text { : probabilitas kaitan antara e dan } \mathrm{E} \text { jika hipotesa } \mathrm{H} \text { benar. } \\
P(e \mid E) & \text { : probabilitas kaitan antara e dan } \mathrm{E} \text { tanpa memandang hipotesa apapun } \\
P(H \mid E) & \text { : probabilitas hipotesa } \mathrm{H} \text { jika terdapat evidence } \mathrm{E} .
\end{array}
$$

Menurut Arhami (2005), dalam bidang kedokteran teorema Bayes dikenal lebih banyak diterapkan dalam logika kedokteran modern. Teorema ini lebih banyak diterapkan pada hal-hal yang berkenaan dengan diagnose secara statistik yang berhubungan dengan probabilitas serta kemungkinan dari penyakit dan gejala-gejala yang berkaitan.

Secara umum teorema Bayes dengan E kejadian dan hipnotis H dapat dituliskan dalam bentuk :

$$
\begin{aligned}
P\left(H_{i} \mid E\right) & =\frac{P\left(E \cap H_{i}\right)}{\sum_{j} P\left(E \cap H_{i}\right)} \\
& =\frac{P\left(E \| H_{i}\right) P\left(H_{i}\right)}{\sum_{j} P\left(E \| H_{j}\right) P\left(H_{j}\right.}
\end{aligned}
$$




$$
=\frac{P\left(E \mid H_{i}\right) P\left(H_{i}\right)}{P(E)}
$$

Berikut ini adalah contoh penghitungan menggunakan probabilitas Bayes :

Seorang dokter mengetahui bahwa penyakit maningitis menyebabkan "stiff neck" adalah 50\%. Probabilitas pasien menderita meningitis adalah 1/50000 dan probabilitas pasien menderita stiff neck adalah $1 / 20$ dari nilai-nilai tersebut.

Didapatkan :

$$
\begin{aligned}
& \mathrm{P}(\text { stiff neck } \mid \text { meningitis })=50 \%=0,5 \\
& \mathrm{P}(\text { meningitis })=1 / 50000 \\
& \mathrm{P}(\text { stiff neck })=1 / 20
\end{aligned}
$$

Maka :

$$
\begin{aligned}
P(\text { meningitis } \mid \text { stiffneck })= & \frac{P(\text { meningitis } \| \text { stiffneck }) x P(\text { meningitis })}{P(\text { stiffneck })} \\
& =\frac{\frac{5}{10} x \frac{1}{50000}}{\frac{1}{10}} \\
& =\frac{1}{5000}
\end{aligned}
$$

Hasil di atas menunjukkan bahwa hanya 1 diantara 5000 pasien yang mengalami stiff neck.

\subsection{Teorema Bayes}

Menurut Muhamad Rachli (2007) sebelum mendeskripsikan bagaimana teorema Bayes digunakan untuk klasifikasi, disusun masalah klasifikasi dari sudut pandang statistik. Jika $X$ melambangkan set atribut data dan $Y$ melambangkan kelas variabel. Jika variabel kelas memiliki hubungan non deterministic dengan atribut, maka dapat diperlakukan $X$ dan $Y$ sebagai variabel acak dan menangkap hubungan peluang menggunakan $P(Y \mid X)$. Peluang bersyarat ini juga dikenal dengan posterior peluang untuk $Y$, dan sebaliknya peluang prior $P(Y)$.

Berikut adalah contoh kasus tentang peminjaman yang gagal. Selama fase training, perlu mempelajari peluang posterior untuk seluruh kombinasi $X$ dan $Y$ berdasar informasi yang diperoleh dari training data. Dengan mengetahui peluang ini, test record $X^{\prime}$ dapat diklasifikasikan dengan menemukan kelas $Y^{\prime}$ yang memaksimalkan peluang posterior $P(Y \mid X)$. Untuk mengilustrasikan pendekatan ini, perhatikan tugas memprediksi apakah seseorang akan gagal mengembalikan pinjamannya. Tabel 1 memperlihatkan training data dengan atribut : Home Owner, Marital Status, dan Annual Income. Peminjam yang gagal membayar diklasifikasikan sebagai seseorang yang membayar kembali pinjaman sebagai No.

Tabel 1 : Tabel Contoh Training set untuk masalah kegagalan pinjaman.

\begin{tabular}{ccccc} 
Tid & Biner & Kategorikal & Kontinyu & Kelas \\
\hline 1 & Yes & $\begin{array}{c}\text { Marital } \\
\text { Status }\end{array}$ & $\begin{array}{c}\text { Annual } \\
\text { Income }\end{array}$ & $\begin{array}{c}\text { Defaulted } \\
\text { Borrower }\end{array}$ \\
\hline 2 & No & Single & $120 \mathrm{~K}$ & No \\
3 & No & Single & $700 \mathrm{~K}$ & No \\
4 & Yes & Married & $120 \mathrm{~K}$ & No \\
5 & No & Divorce & $95 \mathrm{~K}$ & Yes
\end{tabular}




\begin{tabular}{lllll}
6 & No & Married & $60 \mathrm{~K}$ & No \\
7 & Yes & Divorce & $220 \mathrm{~K}$ & No \\
8 & No & Single & $85 \mathrm{~K}$ & Yes \\
9 & No & Married & $75 \mathrm{~K}$ & No \\
10 & No & Single & $90 \mathrm{~K}$ & Yes \\
\hline
\end{tabular}

Jika diberikan test record dengan atribut berikut : $X=($ Home Owner $=$ No, Marital Status $=$ Married, Annual Income $=\$ 120 \mathrm{~K})$. Untuk mengklasifikasi record, perlu dihitung peluang posterior $P(Y e s \mid X), \quad P(N o \mid X)$ berdasar informasi yang tersedia pada training data. Jika $P(Y e s \mid X)>P(N o \mid X)$, maka record diklasifikasikan sebagai Yes, sebaliknya diklasifikasikan sebagai No.

Untuk mengestimasi peluang posterior secara akurat untuk setiap kombinasi label kelas yang mungkin dan nilai atribut adalah masalah sulit karena membutuhkan training set sangat besar, meski untuk jumlah moderate atribut. Teorema Bayes bermanfaat karena menyediakan pernyataan istilah peluang posterior dari peluang prior $P(Y)$, peluang kelas bersyarat $P(X \mid Y)$ dan bukti $P(X)$ :

$$
P(Y \mid X)=\frac{P(X \mid Y) x P(Y)}{P(X)}
$$

Ketika membandingkan peluang posterior untuk nilai $Y$ berbeda, istilah dominator, $P(X)$, selalu tetap, sehingga dapat diabailan. Peluang prior $P(Y)$ dapat dengan mudah diestimasi dari training set dengan menghitung pecahan training record yang dimiliki tiap kelas. Untuk mengestimasi peluang kelas bersyarat $P(X \mid Y)$, dihadirkan dua implementasi metoda klasifikasi Bayesian.

\subsection{Naive Bayes Classifier}

Naive bayes classifier mengestimasi peluang kelas bersyarat dengan mengasumsikan bahwa atribut adalah independen secara bersyarat yang diberikan dengan label kelas $y$. Asumsi independen bersyarat dapat dinyatakan dalam bentuk berikut (Muhamad Rachli, 2007)

$$
P(X \mid Y=y)=\prod_{i=1}^{d} P\left(X_{i} \mid Y=y\right)
$$

dengan tiap set atribut $X=\left\{X_{1}, X_{2}, \ldots, X_{d}\right\}$ terdiri dari $d$ atribut.

\section{Contoh naive bayes classifier}

Perhatikan data set yang ditunjukkan Tabel 2, peluang kelas bersyarat dapat dihitung untuk pengkategorian tiap atribut, bersama dengan sampel mean dan varian untuk atribut kontinyu menggunakan metodologi yang dijelaskan pada bagian sebelumnya. Peluang ini diringkas pada Tabel 3.

Tabel 2 : Contoh Tabel Naive Bayes Classifier untuk masalah klasifikasi pinjaman.

\begin{tabular}{cclcc}
\hline Tid & $\begin{array}{c}\text { Home } \\
\text { Owner }\end{array}$ & $\begin{array}{c}\text { Marital } \\
\text { Status }\end{array}$ & $\begin{array}{c}\text { Annual } \\
\text { Income }\end{array}$ & $\begin{array}{c}\text { Defaulted } \\
\text { Borrower }\end{array}$ \\
\hline 1 & Yes & Single & $120 \mathrm{~K}$ & No \\
2 & No & Married & $100 \mathrm{~K}$ & No \\
3 & No & Single & $70 \mathrm{~K}$ & No \\
4 & Yes & Married & $120 \mathrm{~K}$ & No \\
5 & No & Divorce & $95 \mathrm{~K}$ & Yes \\
6 & No & Married & $60 \mathrm{~K}$ & No
\end{tabular}




\begin{tabular}{lllll}
7 & Yes & Divorce & $220 \mathrm{~K}$ & No \\
8 & No & Single & $85 \mathrm{~K}$ & Yes \\
9 & No & Married & $75 \mathrm{~K}$ & No \\
10 & No & Single & $90 \mathrm{~K}$ & Yes \\
\hline
\end{tabular}

Tabel 3 : Peluang untuk mean dan varian

\begin{tabular}{|}
$\mathrm{P}($ Home Owner $=$ Yes $\mid$ No $)=3 / 7$ \\
$\mathrm{P}($ Home Owner $=$ No $\mid$ No $)=4 / 7$ \\
$\mathrm{P}($ Home Owner $=$ Yes $\mid$ Yes $)=0$ \\
$\mathrm{P}($ Home Owner $=$ No $\mid$ Yes $)=1$ \\
$\mathrm{P}($ Marital Status $=$ Single $\mid$ No $)=2 / 7$ \\
$\mathrm{P}($ Marital Status $=$ Divorce $\mid$ No $)=1 / 7$ \\
$\mathrm{P}($ Marital Status $=$ Married $\mid$ No $)=4 / 7$ \\
$\mathrm{P}($ Marital Status $=$ Single $\mid$ Yes $)=2 / 3$ \\
$\mathrm{P}($ Marital Status $=$ Divorce $\mid$ Yes $)=1 / 3$ \\
$\mathrm{P}($ Marital Status $=$ Married $\mid$ No $)=0$ \\
For Annual Income $:$ \\
If class $=$ No $:$ sample mean $=110$ \\
Sample variance $=2975$ \\
If class $=$ Yes $:$ sample mean $=90$ \\
Sample variance $=25$
\end{tabular}

Untuk memprediksi label kelas test record $\mathrm{X}=($ Home Owner $=$ No, Marital Status $=$ Married, Income $=\$ 120 \mathrm{~K})$, perlu menghitung peluang posterior $P(N o \mid X)$ dan $P(\operatorname{Yes} \mid X)$. Mengingat dari diskusi sebelumnya bahwa peluang posterior ini dapat diestimasi dengan menghitung produk antara peluang prior $P(Y)$ dan peluang kelas bersyarat $\prod_{i} P\left(X_{i} \mid Y\right)$, yang bersesuaian dengan pembilang pada sisi kanan Persamaan 5.

Peluang prior tiap kelas dapat diestimasi dengan menghitung pecahan tiap training record yang dimiliki tiap kelas. Karena ada tiga record yang dimiliki kelas Yes dan tujuh record yang dimiliki kelas No, $P($ Yes $)=0.3$ dan $P(N o)=0.7$. Menggunakan informasi yang disediakan pada Tabel 3, peluang kelas besyarat dapat dihitung sebagai berikut.

$$
\begin{aligned}
P(X \mid N o)= & \mathrm{P}(\text { Home Owner }=\text { No } \mid \text { No }) \times \mathrm{P}(\text { Status }=\text { Married } \mid \text { No }) \\
& \times \mathrm{P}(\text { Annual Income }=\$ 120 \mathrm{~K} \mid \text { No }) \\
= & 4 / 7 \times 4 / 7 \times 0.0072=0.0024 . \\
P(X \mid \text { Yes })= & P(\text { Home Owner }=\text { No } \mid \text { Yes }) \times \mathrm{P}(\text { Status }=\text { Married } \mid \text { Yes }) \\
& \times \mathrm{P}(\text { Annual Income }=\$ 120 \mathrm{~K} \mid \text { Yes }) \\
= & 1 \times 0 \times 1.2 \times 10^{-9}=0 .
\end{aligned}
$$

Dengan menggabungkan, peluang posterior untuk kelas No adalah $P(N o \mid X)=\alpha x 7 / 10 x 0.0024=0.0016 \alpha, \quad$ dengan $\quad \alpha=1 / P(X) \quad$ adalah istilah tetap. Menggunakan pendekatan yang sama, dapat ditunjukkan bahwa peluang posterior untuk kelas Yes adalah nol karena peluang kelas bersyarat adalah nol. Karena $P(N o \mid X)>P(\operatorname{Yes} \mid X)$, maka record diklasifikasikan sebagai $\mathrm{No}$. 


\subsection{Metode Bayesian}

Metode Bayesian yang saya gunakan adalah Naive bayes classifier. Naive bayes classifier mengestimasi peluang kelas bersyarat dengan mengasumsikan bahwa atribut adalah independen secara bersyarat yang diberikan dengan label kelas $y$. Asumsi independen bersyarat dapat dinyatakan dalam bentuk berikut :

$$
P(X \mid Y=y)=\prod_{i=1}^{d} P\left(X_{i} \mid Y=y\right)
$$

\section{PEMBAHASAN}

Perhitungan manual dengan menggunakan Metode Bayesian dapat dilihat di tabel 4 yang ada dibawah ini. Penyimpangan yang terkait dengan gejala yang diinputkan dihitung dengan menggunakan tabel knowledge base. Gejala yang dialami ditandai dengan warna merah pada nomer urutnya yaitu :

\section{USIA 6 SAMPAI 9 BULAN}

$\mathrm{a}=$ dapat duduk tanpa dibantu

$\mathrm{b}=$ dapat tengkurap dan berbalik sendiri

$\mathrm{c}=$ dapat merangkak meraih benda atau mendekati orang

$\mathrm{d}=$ memindahkan benda dari tangan satu ke tangan yang lain

$\mathrm{e}=$ memegang benda kecil dengan ibu jari dan jari telunjuk

$\mathrm{f}=$ bergembira dengan melempar benda-benda kasar

$\mathrm{g}=$ mengeluarkan kata-kata yang tanpa arti

$\mathrm{h}=$ mengenal muka anggota-anggota keluarga dan takut kepada orang asing

$\mathrm{I}=$ mulai berpartisipasi dalam permainan tepuk tangan dan sembunyi-sembunyian[4].

Isi data $=$

$1=$ dapat

2 = belum

Tabel 4 : Knowledge Base

\begin{tabular}{|c|c|c|c|c|c|c|c|c|c|c|}
\hline no & $\mathbf{a}$ & $\mathbf{b}$ & $\mathbf{C}$ & D & e & f & g & $\mathbf{h}$ & i & hasil \\
\hline 1 & 1 & 1 & 1 & 1 & 1 & 1 & 1 & 1 & 2 & $\begin{array}{l}\text { keterlambatan perkembangan sosialisasi dan } \\
\text { kemandirian } \\
\text { keterlambatan perkembangan sosialisasi dan }\end{array}$ \\
\hline 2 & 1 & 1 & 1 & 1 & 1 & 1 & 1 & 2 & 1 & kemandirian \\
\hline 3 & 1 & 1 & 1 & 1 & 1 & 1 & 2 & 1 & 1 & keterlambata kemampuan bicara / bahasa \\
\hline 4 & 1 & 1 & 1 & 1 & 1 & 2 & 1 & 1 & 1 & keterlambatan perkembangan emosi \\
\hline 5 & 1 & 1 & 1 & 1 & 2 & 1 & 1 & 1 & 1 & keterlambatan perkembangan motorik halus \\
\hline 6 & 1 & 1 & 1 & 2 & 1 & 1 & 1 & 1 & 1 & keterlambatan perkembangan motorik halus \\
\hline 7 & 1 & 1 & 2 & 1 & 1 & 1 & 1 & 1 & 1 & keterlambatan perkembangan motorik kasar \\
\hline 8 & 1 & 2 & 1 & 1 & 1 & 1 & 1 & 1 & 1 & keterlambatan perkembangan motorik kasar \\
\hline 9 & 2 & 1 & 1 & 1 & 1 & 1 & 1 & 1 & 1 & keterlambatan perkembangan motorik kasar \\
\hline 10 & 2 & 2 & 1 & 1 & 1 & 1 & 1 & 1 & 1 & keterlambatan perkembangan motorik kasar \\
\hline 11 & 2 & 2 & 2 & 1 & 1 & 1 & 1 & 1 & 1 & keterlambatan perkembangan motorik kasar \\
\hline 12 & 2 & 2 & 2 & 2 & 1 & 1 & 1 & 1 & 1 & keterlambatan perkembangan motorik halus \\
\hline
\end{tabular}




\begin{tabular}{|c|c|c|c|c|c|c|c|c|c|c|}
\hline 13 & 1 & 1 & 1 & 1 & 1 & 1 & 1 & 2 & 2 & $\begin{array}{l}\text { keterlambatan perkembangan sosialisasi dan } \\
\text { kemandirian }\end{array}$ \\
\hline 14 & 1 & 1 & 1 & 2 & 2 & 1 & 1 & 1 & 1 & keterlambatan perkembangan motorik halus \\
\hline 15 & 1 & 1 & 2 & 2 & 2 & 2 & 1 & 1 & 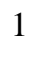 & $\begin{array}{l}\text { keterlambatan perkembangan motorik halus } \\
\text { keterlambatan perkembangan sosialisasi dan }\end{array}$ \\
\hline 16 & 1 & 1 & 1 & 1 & 1 & 1 & 2 & 2 & 2 & $\begin{array}{l}\text { kemandirian } \\
\text { keterlambatan perkembangan sosialisasi dan }\end{array}$ \\
\hline 17 & 1 & 1 & 1 & 1 & 1 & 1 & 2 & 2 & 1 & kemandirian \\
\hline 18 & 1 & 2 & 2 & 1 & 1 & 1 & 1 & 1 & 1 & keterlambatan perkembangan motorik kasar \\
\hline 19 & 2 & 1 & 2 & 1 & 1 & 1 & 1 & 1 & 1 & keterlambatan perkembangan motorik kasar \\
\hline 20 & 1 & 1 & 1 & 2 & 2 & 2 & 1 & 1 & 1 & keterlambatan perkembangan motorik halus \\
\hline
\end{tabular}

\section{Tahap 1 menghitung jumlah class/label}

$\mathrm{P}(\mathrm{Y}=$ halus $)=6 / 20$ ' jumlah data "motorik halus" pada komom 'HASIL' dibagi jumlah data $\mathrm{P}(\mathrm{Y}=$ kasar $)=7 / 20$ ' jumlah data "motorik kasar" pada komom 'HASIL' dibagi jumlah data $\mathrm{P}(\mathrm{Y}=$ bicara $)=1 / 20$ ' jumlah data "kemampuan bicara” pada komom 'HASIL' dibagi jumlah data $\mathrm{P}(\mathrm{Y}=$ emosi $)=1 / 20$ ' jumlah data 'kemampuan bicara” pada komom 'HASIL' dibagi jumlah data $\mathrm{P}(\mathrm{Y}=$ sosialisasi $)=5 / 20$

\section{Tahap 2 menghitung jumlah kasus yang sama dengan class yang sama}

$$
\begin{array}{ll}
\mathrm{P}(\mathrm{a}=\text { dapat } \mid \mathrm{Y}=\text { halus })=5 / 6 & \mathrm{P}(\mathrm{f}=\text { dapat } \mid \mathrm{Y}=\text { halus })=4 / 6 \\
\mathrm{P}(\mathrm{a}=\text { dapat } \mid \mathrm{Y}=\text { kasar })=3 / 7 & \mathrm{P}(\mathrm{f}=\text { dapat } \mid \mathrm{Y}=\text { kasar })=7 / 7 \\
\mathrm{P}(\mathrm{a}=\text { dapat } \mid \mathrm{Y}=\text { bicara })=1 / 1 & \mathrm{P}(\mathrm{f}=\text { dapat } \mid \mathrm{Y}=\text { bicara })=1 / 1 \\
\mathrm{P}(\mathrm{a}=\text { dapat } \mid \mathrm{Y}=\text { emosi })=1 / 1 & \mathrm{P}(\mathrm{f}=\text { dapat } \mid \mathrm{Y}=\text { emosi })=0 / 1 \\
\mathrm{P}(\mathrm{a}=\text { dapat } \mid \mathrm{Y}=\text { sosialisasi })=5 / 5 & \mathrm{P}(\mathrm{f}=\text { dapat } \mid \mathrm{Y}=\text { sosialisasi })=5 / 5 \\
\mathrm{P}(\mathrm{a}=\text { belum } \mid \mathrm{Y}=\text { halus })=1 / 6 & \\
\mathrm{P}(\mathrm{a}=\text { belum } \mid \mathrm{Y}=\text { kasar })=4 / 7 & \mathrm{P}(\mathrm{f}=\text { belum } \mid \mathrm{Y}=\text { halus })=2 / 6 \\
\mathrm{P}(\mathrm{a}=\text { belum } \mid \mathrm{Y}=\mathrm{b} \text { icara })=0 / 1 & \mathrm{P}(\mathrm{f}=\text { belum } \mid \mathrm{Y}=\text { kasar })=0 / 7 \\
\mathrm{P}(\mathrm{a}=\text { belum } \mid \mathrm{Y}=\text { emosi })=0 / 1 & \mathrm{P}(\mathrm{f}=\text { belum } \mid \mathrm{Y}=\mathrm{b} \text { icara })=0 / 1 \\
\mathrm{P}(\mathrm{a}=\text { belum } \mid \mathrm{Y}=\text { sosialisasi })=0 / 5 & \mathrm{P}(\mathrm{f}=\text { belum } \mid \mathrm{Y}=\text { emosi })=1 / 1 \\
& \mathrm{P}(\mathrm{f}=\text { belum } \mid \mathrm{Y}=\text { sosialisasi })=0 / 5 \\
\mathrm{P}(\mathrm{b}=\text { dapat } \mid \mathrm{Y}=\text { halus })=5 / 6 & \\
\mathrm{P}(\mathrm{b}=\text { dapat } \mid \mathrm{Y}=\text { kasar })=3 / 7 & \\
\mathrm{P}(\mathrm{b}=\text { dapat } \mid \mathrm{Y}=\text { bicara })=1 / 1 & \mathrm{P}(\mathrm{g}=\text { dapat } \mid \mathrm{Y}=\text { halus })=6 / 6 \\
\mathrm{P}(\mathrm{b}=\text { dapat } \mid \mathrm{Y}=\text { emosi })=1 / 1 & \mathrm{P}(\mathrm{g}=\text { dapat } \mid \mathrm{Y}=\text { kasar })=7 / 7 \\
\mathrm{P}(\mathrm{b}=\text { dapat } \mid \mathrm{Y}=\text { sosialisasi })=5 / 5 & \mathrm{P}(\mathrm{g}=\text { dapat } \mid \mathrm{Y}=\text { bicara })=0 / 1 \\
& \mathrm{P}(\mathrm{g}=\text { dapat } \mid \mathrm{Y}=\text { emosi })=1 / 1 \\
& \mathrm{P}(\mathrm{g}=\text { dapat } \mid \mathrm{Y}=\text { sosialisasi })=3 / 5
\end{array}
$$




$$
\begin{aligned}
& \mathrm{P}(\mathrm{b}=\text { belum } \mid \mathrm{Y}=\text { halus })=1 / 6 \\
& \mathrm{P}(\mathrm{b}=\text { belum } \mid \mathrm{Y}=\text { kasar })=4 / 7 \\
& \mathrm{P}(\mathrm{b}=\text { belum } \mid \mathrm{Y}=\mathrm{b} \text { icara })=0 / 1 \\
& \mathrm{P}(\mathrm{b}=\text { belum } \mathrm{Y}=\text { emosi })=0 / 1 \\
& \mathrm{P}(\mathrm{b}=\text { belum } \mid \mathrm{Y}=\text { sosialisasi })=0 / 5
\end{aligned}
$$

$$
\begin{aligned}
& \mathrm{P}(\mathrm{c}=\text { dapat } \mid \mathrm{Y}=\text { halus })=4 / 6 \\
& \mathrm{P}(\mathrm{c}=\text { dapat } \mid \mathrm{Y}=\text { kasar })=3 / 7 \\
& \mathrm{P}(\mathrm{c}=\text { dapat } \mid \mathrm{Y}=\text { bicara })=1 / 1 \\
& \mathrm{P}(\mathrm{c}=\text { dapat } \mid \mathrm{Y}=\text { emosi })=1 / 1 \\
& \mathrm{P}(\mathrm{c}=\text { dapat } \mid \mathrm{Y}=\text { sosialisasi })=5 / 5 \\
& \mathrm{P}(\mathrm{c}=\text { belum } \mid \mathrm{Y}=\text { halus })=2 / 6 \\
& \mathrm{P}(\mathrm{c}=\text { belum } \mid \mathrm{Y}=\text { kasar })=4 / 7 \\
& \mathrm{P}(\mathrm{c}=\text { belum } \mid \mathrm{Y}=\mathrm{b} \text { icara })=0 / 1 \\
& \mathrm{P}(\mathrm{c}=\text { belum } \mid \mathrm{Y}=\text { emosi })=0 / 1 \\
& \mathrm{P}(\mathrm{c}=\text { belum } \mid \mathrm{Y}=\text { sosialisasi })=0 / 5
\end{aligned}
$$

$\mathrm{P}(\mathrm{d}=$ dapat $\mid \mathrm{Y}=$ halus $)=1 / 6$

$\mathrm{P}(\mathrm{d}=$ dapat $\mid \mathrm{Y}=$ kasar $)=7 / 7$

$\mathrm{P}(\mathrm{d}=$ dapat $\mid \mathrm{Y}=$ bicara $)=1 / 1$

$\mathrm{P}(\mathrm{d}=$ dapat $\mid \mathrm{Y}=$ emosi $)=1 / 1$

$\mathrm{P}(\mathrm{d}=$ dapat $\mid \mathrm{Y}=$ sosialisasi $)=5 / 5$

$\mathrm{P}(\mathrm{d}=$ belum $\mid \mathrm{Y}=$ halus $)=5 / 6$

$\mathrm{P}(\mathrm{d}=$ belum $\mid \mathrm{Y}=$ kasar $)=0 / 7$

$\mathrm{P}(\mathrm{d}=$ belum $\mid \mathrm{Y}=\mathrm{b}$ icara $)=0 / 1$

$\mathrm{P}(\mathrm{d}=$ belum $\mid \mathrm{Y}=$ emosi $)=0 / 1$

$\mathrm{P}(\mathrm{d}=$ belum $\mid \mathrm{Y}=$ sosialisasi $)=0 / 5$
$\mathrm{P}(\mathrm{g}=$ belum $\mid \mathrm{Y}=$ halus $)=0 / 6$

$\mathrm{P}(\mathrm{g}=$ belum $\mid \mathrm{Y}=$ kasar $)=0 / 7$

$\mathrm{P}(\mathrm{g}=$ belum $\mid \mathrm{Y}=\mathrm{b}$ icara $)=1 / 1$

$\mathrm{P}(\mathrm{g}=$ belum $\mid \mathrm{Y}=$ emosi $)=0 / 1$

$\mathrm{P}(\mathrm{g}=$ belum $\mid \mathrm{Y}=$ sosialisasi $)=2 / 5$

$\mathrm{P}(\mathrm{h}=$ dapat $\mid \mathrm{Y}=$ halus $)=6 / 6$

$\mathrm{P}(\mathrm{h}=$ dapat $\mid \mathrm{Y}=$ kasar $)=7 / 7$

$\mathrm{P}(\mathrm{h}=$ dapat $\mid \mathrm{Y}=$ bicara $)=1 / 1$

$\mathrm{P}(\mathrm{h}=$ dapat $\mid \mathrm{Y}=$ emosi $)=1 / 1$

$\mathrm{P}(\mathrm{h}=$ dapat $\mid \mathrm{Y}=$ sosialisasi $)=1 / 5$

$\mathrm{P}(\mathrm{h}=$ belum $\mid \mathrm{Y}=$ halus $)=0 / 6$

$\mathrm{P}(\mathrm{h}=$ belum $\mid \mathrm{Y}=$ kasar $)=0 / 7$

$\mathrm{P}(\mathrm{h}=$ belum $\mid \mathrm{Y}=\mathrm{b}$ icara $)=0 / 1$

$\mathrm{P}(\mathrm{h}=$ belum $\mid \mathrm{Y}=$ emosi $)=0 / 1$

$\mathrm{P}(\mathrm{h}=$ belum $\mid \mathrm{Y}=$ sosialisasi $)=4 / 5$

$\mathrm{P}(\mathrm{i}=$ dapat $\mid \mathrm{Y}=$ halus $)=6 / 6$

$\mathrm{P}(\mathrm{i}=$ dapat $\mid \mathrm{Y}=$ kasar $)=7 / 7$

$\mathrm{P}(\mathrm{i}=$ dapat $\mid \mathrm{Y}=$ bicara $)=1 / 1$

$\mathrm{P}(\mathrm{i}=$ dapat $\mid \mathrm{Y}=$ emosi $)=1 / 1$

$\mathrm{P}(\mathrm{i}=$ dapat $\mid \mathrm{Y}=$ sosialisasi $)=2 / 5$

$\mathrm{P}(\mathrm{i}=$ belum $\mid \mathrm{Y}=$ halus $)=0 / 6$

$\mathrm{P}(\mathrm{i}=$ belum $\mid \mathrm{Y}=$ kasar $)=0 / 7$

$\mathrm{P}(\mathrm{i}=$ belum $\mid \mathrm{Y}=\mathrm{b}$ icara $)=0 / 1$

$\mathrm{P}(\mathrm{i}=$ belum $\mid \mathrm{Y}=$ emosi $)=0 / 1$

$\mathrm{P}(\mathrm{i}=$ belum $\mid \mathrm{Y}=$ sosialisasi $)=3 / 5$

$\mathrm{P}(\mathrm{e}=$ dapat $\mid \mathrm{Y}=$ halus $)=2 / 6$

$\mathrm{P}(\mathrm{e}=$ dapat $\mid \mathrm{Y}=$ kasar $)=7 / 7$

$\mathrm{P}(\mathrm{e}=$ dapat $\mid \mathrm{Y}=$ bicara $)=1 / 1$

$\mathrm{P}(\mathrm{e}=$ dapat $\mid \mathrm{Y}=\mathrm{emosi})=1 / 1$

$\mathrm{P}(\mathrm{e}=$ dapat $\mid \mathrm{Y}=$ sosialisasi $)=5 / 5$ 


$$
\begin{aligned}
& \mathrm{P}(\mathrm{e}=\text { belum } \mid \mathrm{Y}=\text { halus })=4 / 6 \\
& \mathrm{P}(\mathrm{e}=\text { belum } \mid \mathrm{Y}=\text { kasar })=0 / 7 \\
& \mathrm{P}(\mathrm{e}=\text { belum } \mid \mathrm{Y}=\text { b icara })=0 / 1 \\
& \mathrm{P}(\mathrm{e}=\text { belum } \mid \mathrm{Y}=\text { emosi })=0 / 1 \\
& \mathrm{P}(\mathrm{e}=\text { belum } \mid \mathrm{Y}=\text { sosialisasi })=0 / 5
\end{aligned}
$$

Tahap 3 kalikan semua hasil variable sesuai dengan kolom keterlambatan motorik kasar, motorik halus, emosi, dan sosialisasi dan kemandirian.

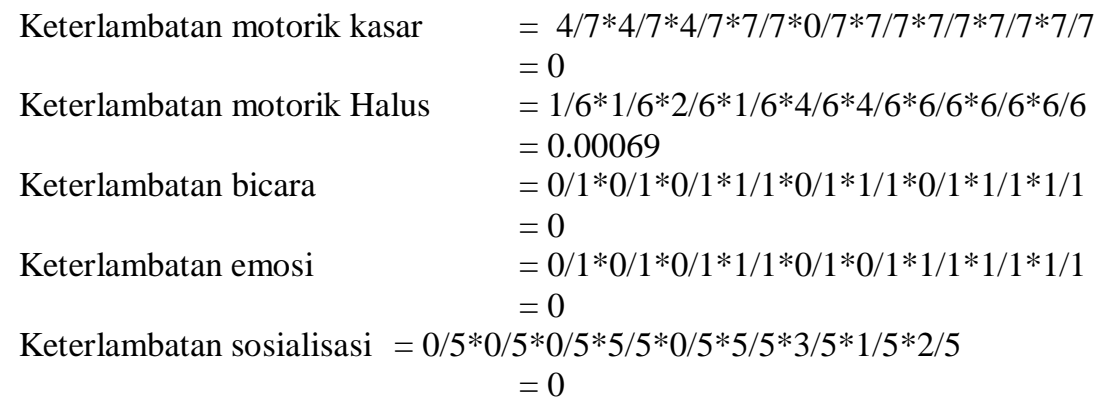

Tahap 4, diambil yang paling maksimal, sehingga dapat disimpilkan bahwa anak tersebut mengalami keterlambatan motorik halus dengan nilai 0.00069 .

Dari beberapa tahapan diatas, maka untuk menentukan penyimpangan pada anak usia $0-3$ tahun dapat dideteksi dengan mudah dengan menggunakan 9 ( Sembilan ) variabel yang digunakan.

\section{KESIMPULAN}

Deteksian penyimpangan pada bayi usia 0 - 3 tahun menggunakan metode Bayesian merupakan suatu deteksi dini untuk mencegah adanya penyimpangan pada bayi, variable yang digunakan dalam mendeteksi penyimpangan pada bayi pada usia 0 - 3 tahun yaitu sikap duduk, tengkurap, merangkak, memindahkan barang dari tangan satu ke tangan yang lain, memegang benda kecil, bergembira dengan melempar benda, mengeluarkan kata-kata, mengenal muka anggota keluarga, berpartisipasi dalam permainan tepuk tangan dan sembunyi-sembunyian[3], sehingga orang tua dapat melakukan pencegahan penyimpangan untuk bayinya, yang meliputi keterlambatan motorik kasar, keterlambatan motorik halus, keterlambatan bicara, keterlambatan emosi dan keterlambatan sosialisasi.

\section{DAFTAR PUSTAKA}

[1] Destiani .2012. Perancangan Analisa Sistem Pakar Penyakit Kulit Pada Anak. Sekolah Tinggi Teknologi Garut. Jawa Barat

[2] Dhany, S. 2009, Perancangan Sistem Pakar Untuk Diagnose Penyakit Anak, Fakultas Ilmu Komputer, Univeritas Sumatra Utara.

[3] Hastuti, Puji. 2011. Standar Asuhan Neonatus, Bayi dan Balita. Akademi Kebidanan Bakti Utama Pati. Pati

[4] Irwanto.2006. Penyimpangan Tumbuh Kembang Anak. OpenUrika Creative Multimedia, Surabaya

[5] Ladjamudin,A. 2005, Analisa dan Desain Sistem Informasi, Graha ilmu, Yogyakarta.

[6] Listiyono. 2008. Merancang dan Membuat Sistem Pakar.Universitas Stikubank. Semarang.

[7] Adriany, Vina .2011. Optimalisasi Perkemangan Anak Usia Dini Melalui Kegiatan Penyuluhan Deteksi Dini Tumbuh Kembang anak. Fakultas Ilmu Pendidikan. Universitas Pendidikan Indonesia. 